\title{
Nurse/ Physician Collaboration and its Relation to Professional Nursing Autonomy as Perceived by Nurses
}

\author{
Mabrouka Hamdy Mohamed El- shamy ${ }^{1}$, Safaa Mohamed El-Demerdash ${ }^{2}$, Aya Ghoneimy \\ Hasanin $^{3}$
}

(1)(B.SC. Nursing ,2010), Nursing Specialist at Menouf Feverish Hospital (2)Assistant. Professor of Nursing Administration, Faculty of Nursing, Tanta University (3)Lecturer of Nursing Administration, Faculty of Nursing, Benha University

\begin{abstract}
Background: poor nurse/ physician collaboration could result in job dissatisfaction, a lack of autonomy, and higher possibility of intention to leave the job and poor health. The study aimed to identify the relation between nurse/physician collaboration and professional nursing autonomy as perceived by nurses. A descriptive correlational design was utilized to conduct this study. Setting: This study conducted at critical care units at Benha University Hospital. The sample of this study included a convenient sample contain 277 nurses. Tool: Two tools were used for data collection, the first tool: Nurse / physician collaboration scale, the second tool: Professional nursing autonomy scale. The study results: Showed that nearly two fifths $(39,4 \%)$ of nurses had low perception level regarding nurse physician collaboration and more than two fifth $(46,9 \%)$ of them had low perception level about professional nursing autonomy. The Conclusion: There was highly statistical significant positive correlation between overall nurses' perception regarding nurse/physician collaboration and overall professional nursing autonomy. The study recommended that: There is a need for further studies that explain the important factors that hindering inter professional collaboration and its negative outcomes.
\end{abstract}

Key words: Collaboration, Nurse/physician, Professional autonomy.

\section{Introduction}

The professions of nursing and medicine together makeup a significant portion of health care providers supporting collaboration between them are essential in the development of appropriate treatment plans that lead to the best patient outcomes .Patients feel the health care team is working together to ensure care delivered is carried out appropriately when they visually observe active collaborative measures (starmer et al.2014).

El Sayed and Sleem (2011) view collaboration as a partnership between both parties in a relationship. These authors defined collaboration "...as the process of joint decision-making among independent parties, involving joint ownership of decisions and collective responsibility for outcomes". Here there is an acknowledgement of the independence of those involved in the decision-making process without any subservience assumed in the relationship. Collaboration in this definition involves not only partnership in the decisions made but also shared responsibility for the decisions made.

Collaboration between nurses and physicians will improve their ability to achieve patient well-being. Furthermore, collaboration and understanding between nursing staff and physicians improves patient 
outcome and the job satisfaction of nurses and may be a factor in the retention of nurses. Trust and integrity playing an important role in effective nurse-physician relationship, valuable information about the patient may not be shared, and orders may be delayed if antagonism, poor communication, and mistrust exist between doctors and nurses (ElHanafy, 2018).

The nurses and physicians collaboration scale dimensions were developed in Japan by Ushiro et al. in 2009. It is divided into three categories, including the sharing of the clinical patient information, the decision-making process; the nurse physician cooperation (Rapetti et al., 2014).

Joint participation cure/care decision making process refers to make the decisions regarding patients' direction of care, problems and discharge together and in consistent manner. Sharing of patient information indicates that nurse and physician share information to verify the effects of treatment and have mutual understanding about the change in the treatment plan. Cooperativeness reflects that nurse and physician help each other, show concern for each other when being tired and the nurse and physician take into account each other's schedule when making plans to treat a patient together (Mohamed, 2016).

Nowadays, autonomy is defined as having the right of making decisions and acting accordingly. Autonomy with regard to nurses, means doing activities within the scope of nursing practice without permission from others. Independent interventions by nurses' means that nurses do not need to get permission from authorities for performing patients' assessment and observation. At the same time, they should strive to make professional relationships with other healthcare workers. All these require professional autonomy for performing nursing duties (Shohani et al., 2018).

Professional autonomy is defined as having the authority to make decisions and the freedom to act in accordance with one's professional knowledge base. This professional knowledge includes caring for culturally and linguistically diverse patients. Nurse autonomy or professional autonomy in nursing (autonomy) refers to the ability to act on one's knowledge and judgment and to provide nursing care within the full scope of practice, as defined by existing professional regulatory and organizational rules( Kuwano et al.2016).

According to Supametaporn, (2013), autonomy classified into; Structural and attitudinal dimensions, Structural or work autonomy is the worker's freedom to make decision based on job requirements, and exists when professional people is in the expected context of their work, to use their judgment in the provision of client services . For attitudinal autonomy, it is described as the belief that one is free to exercise judgment in decision making. It is the manner in which the individual nurses feel and view their work of the profession; and the autonomy of the individual nurses has frequently been examined and discussed as an attitude or perception.

Structural autonomy classified into three components; practice environment, managed care, and educational background. Practice environment is affected by the authority granted by nurses like regulatory policies which vary from one organization to another. In addition managed care enhances planning and coordination of care to eliminate duplication of services, prevent delays in 
patient discharge. Also, educational background includes formal education, clinical training, critical thinking and communication skills (El-ksas, 2015).

\section{Significance of the study}

In fact, collaboration and positive relationships between nurse and physician have been identified as a major factor contributing to positive patient outcomes and quality patient care. It ensures the safety, satisfaction and faster recovery of patients resulting to a lower mortality rate (Franco and Cordero, 2017).

Limited autonomy of nurse has been proposed as a barrier to collaboration. Gaps in collaboration may hinder nurses' ability to actualize their clinical decisions lack of autonomy has been identified repeatedly in nursing research and associated with job dissatisfaction, burnout and leaving nursing, as well as with health outcomes in nursing personal and staff retention. Whereas low autonomy and collaboration were linked to increased incidence and severity of moral distress (Georgiou et al., 2015) .Through my clinical observation I found that when nurse and physician share patient information resulting in improving patient health status and create a sense of collaboration

\section{Aim of study}

The present study aimed to identify the relation between nurse/physician collaboration and professional nursing autonomy as perceived by nurses.

\section{Research questions}

1- What is nurse's perception level toward nurse/physician collaboration?

2-What is nurse's perception level toward professional nursing autonomy?

$\begin{array}{lrr}3 \text {-What is the } \begin{array}{c}\text { relation between } \\ \text { nurse/physician }\end{array} & \text { collaboration }\end{array}$

professional nursing autonomy as perceived by nurse?

\section{Subjects and Methods}

\section{Technical Design}

The technical design includes study design, study setting, subjects and methods and tools that used in data collection.

\section{Research Design}

Descriptive correlational design was utilized to conduct this study.

\section{Setting}

The study was conducted at critical care units at Benha University Hospital:(Intensive care unit ,Intermediate care unit ,Coronary care unit, pediatric care unit ,Dialysis care unit ,Cardiology care unit, Chestology care unit ,Emergency care unit, Incubator care unit)

The total number of bed at this hospital is (880).The hospital composed of three separated buildings; Medical building (478 beds), Surgical building (384 beds) and Ophthalmology building (18 beds). The nine critical care units at Benha University Hospital that mentioned above include 112 beds.

\section{Subjects}

It included a convenient sample nurses who are available in the above mentioned study setting at the time of study and accept to participate in this study with at least one year of experience. The total number was 277 nurses and their educational qualification was Diploma degree in nursing (24 nurses), Nursing institute (91 nurses), Bachelor degree in nursing (152 nurses), and others (10 nurses) distributed as following:- 
Table (A): Distribution of Nurses According to Their Units.

\begin{tabular}{|c|c|}
\hline $\begin{array}{c}\text { Units } \\
\text { (9 units) }\end{array}$ & $\begin{array}{c}\text { Number of } \\
\text { nurses }=277\end{array}$ \\
\hline Intensive care unit & 60 \\
\hline Intermediate care unit & 18 \\
\hline Coronary care unit & 33 \\
\hline pediatric care unit & 30 \\
\hline Dialysis care unit & 38 \\
\hline Cardiology care unit & 25 \\
\hline Chestology care unit & 16 \\
\hline Emergency care unit & 23 \\
\hline Incubator care unit & 34 \\
\hline Total & 277 \\
\hline
\end{tabular}

Tools for data collection:

To collect data for this study the following tools were used:

The First Tool: Nurse / physician collaboration scale:

It was developed by (Ushiro et al., 2009) and it was adopted by investigator. It measures nurse's perception toward nurse /physician collaboration it included two parts:

- Part I: Included nurses' personal characteristics as (age, gender, educational level, marital status, units, years of experience,).

- Part II: consisted of 23 items divided into 3 dimensions as following:

Table (B): Dimensions of nurse / physician collaboration scale.

\begin{tabular}{|l|c|}
\hline \multicolumn{1}{|c|}{$\begin{array}{c}\text { Dimensions of nurse / } \\
\text { physician collaboration } \\
\text { scale }\end{array}$} & $\begin{array}{c}\text { Number of } \\
\text { Items }\end{array}$ \\
\hline $\begin{array}{l}\text { 1) Joint participation in cure / } \\
\text { care decision making. }\end{array}$ & 10 items \\
\hline $\begin{array}{l}\text { 2) Sharing of patients' } \\
\text { information. }\end{array}$ & 7 items \\
\hline 3) Degree of cooperation. & 23items \\
\hline Total & 23items \\
\hline
\end{tabular}

Scoring system: Nurses responses were measured on a five point -Likert as following: strongly agree (5), agree (4), neutral (3), disagree (2) and strongly disagree (1). The overall score level ranging from (23115).Scores were summed up and converted into percent scores. The nurses' perception level regarding nurse / physician collaboration determined as following:

- Low perception level if the percent scores $(<60 \%)$.

- Moderate perception level if the percent scores (60-75\%).

- High perception level if the percent scores $(>75 \%)$.

\section{The Second Tool: Professional nursing autonomy scale:}

It was developed by (Elksas, 2015) and it was modified by the investigator. It included differential items to determine nurses' perception toward professional nursing autonomy .It consisted of 44 items which are classified into two main dimensions namely ;structural autonomy (34items) and attitudinal autonomy(10 items).Structural autonomy consisted of three sub- dimensions namely: Nursing Practice Environment(14 items), Nursing Care Management(11 items), Educational background for nurses(9 items).

Scoring system: Nurses responses were measured on a five point -Likert scale as following: very likely to happen (5), likely to happen (4), very un likely to happen (3), unlikely to happen (2) and little happen (1). Scores were summed up and converted into percent scores .The nurses' perception level regarding professional nursing autonomy determined as following:

- Low perception level of if the percent scores $(<60 \%)$.

- Moderate perception level if the percent scores $(60-75 \%)$. 
- High perception level if the percent scores $(>75 \%)$.

\section{Administrative design}

An official permission was issued from Dean of the Faculty of Nursing to the Director of Benha University Hospital to obtain the approval for data collection, the objectives and the nature of the study were explained and then it was possible to carry out the study with minimum resistance.

\section{Operational design}

The study passed over the following phases: Preparatory phase, pilot study and field work phase.

\section{Preparatory phase}

A review of the past, current Arabic and English related literature covering various aspects of the problem was done, using available books, articles, periodicals, and magazines to get acquainted with the research problem and develop the study tools.

Validity of the study tools were tested by panel of experts consisted of one Assistant Professor of Nursing Administration at Faculty of Nursing Benha University and one Professor of Nursing Administration at Faculty of Nursing Menofia University. Two Assistant Professors of Nursing Administration and one Lecturer of Nursing Administration at Faculty of Nursing Tanta University. Minor modifications and rephrasing of some statements were done based on jury's opinions.

\section{Reliability of the tools}

Reliability of nurse / physician collaboration scale was measured by using Cronbach's alpha and the value was $(\alpha=0.888)$. Reliability of professional nursing autonomy scale was measured by using Cronbach's alpha and the value was $(\alpha=0.892)$.

Pilot study
Pilot study was conducted to assess tool clarity and applicability. It had also served in estimating the time needed for filling the form. The study was tested on $10 \%$ of total subjects; it was done on 28 nurses from Benha University Hospital. Nurses were included in the main subject. The clarification for statements related to their translation to Arabic was done.

\section{Implementation phase}

- Each nurse was met after explaining the purpose of the study and getting agreement of nurses to participate in the research.

- Data had been collected from nurses in the above mentioned study at Benha University Hospital.

- Collection of data took three months at Benha University Hospital from beginning of October, 2019 to the end of December, 2019. The investigator met each nurse individually for study sample for three days per a week.

- The time needed to complete the two scales was (20-30 minutes)

- The appropriate time of data collection was according to type of work and workload of each department, sometimes it was in the middle of the shift and other time before the end of the shift.

\section{Ethical Considerations}

The study was conducted with careful attention to ethical standards of research and rights of the participants:-

\section{Informed consent:}

The respondent rights was protected by ensuring voluntary participation, so the informed consent was obtained by explaining purpose, nature time of conducting the study, 
potential benefits of the study, how data will be collected, expected outcomes and the respondent rights to withdrawing from the research study at any time in case of violation of his rights.

\section{Anonymity and confidentiality:}

-Spearman coefficient is a test used to study correlation between two distributed abnormally quantitative variables.

\section{Statistical design}

Data were verified prior to entry into computer. Data were fed to the computer and analyzed using IBM SPSS (software package version 20.0). Qualitative data were described using number and percent. Quantitative data were described using mean and standard deviation. Significance of the obtained results was judged at the $5 \%$ level. A significance level value was considered when $\mathrm{p}$-value $\leq$ 0.05 and a highly significance level was considered when $\mathrm{p}$-value $\leq 0.001$, while $\mathrm{p}$ value $>0.05$ indicated non- significance results. -Pearson coefficient (r) is a test used to study correlation between two normally distributed quantitative variables.

\section{Results}

Table (1) illustrates the percentage distribution of nurses according to their personal characteristics. It shows that the majority $(80.5 \%-82.3 \%)$ of nurses had age less than 30years old and were females respectively.Also, $(54,9 \%)$ ) of them had Bachelor degree in nursing. In addition, (77.6\%) of nurses were married. Regarding department, $(21,7 \%)$ of nurses were working at Intensive care unit. Concerning years of experience, the majority $(88,4 \%)$ of them had
The respondent was assured that the data will be treated as strictly confidential; furthermore, the respondent anonymity was maintained as they will not require mentioning their names.

\section{Scientific honesty:}

To ensure scientific honesty, the researcher uses bracketing and intuiting to avoid bias. less than10 years. As well as, (57.4\%) of the nurses had taken courses.

Figure (1) illustrates the total perception levels of nurses regarding nurse physician collaboration. It shows that $(39,4 \%)$ of nurses had low perception level regarding nurse physician collaboration .while, (22, 7\%)of them had high perception level .

Table (2) illustrates the total perception levels of nurses regarding nurse physician collaboration dimensions. It shows that $(48.4 \%)$ of nurses had low perception level regardingJoint participation in cure / care decision making dimension and (46.9\%-41, 9\%)of nurses had moderate perception level regarding sharing of patients' information and degree of cooperation dimensions respectively.

Figure (2) illustrates total perception levels of nurses regarding professional nursing autonomy. It shows that $(46,9 \%)$ of nurses had low perception level about professional nursing autonomy, while $(14,1 \%)$ of them had moderate perception level.

Table (3) shows that there was highly statistical significant positive correlation between overall nurses' perception regarding nurse/physician collaboration and overall professional nursing autonomy at $(\mathrm{P} \leq 0.001)$. 
Table (1): Percentage distribution of nurses according to their personal characteristics $(n=$ 277).

\begin{tabular}{|c|c|c|}
\hline Personal characteristics & No & $\%$ \\
\hline $\begin{array}{l}\text { Age } \\
<30 \text { years } \\
30-45 \text { years } \\
>45 \text { years }\end{array}$ & $\begin{array}{c}223 \\
54 \\
0\end{array}$ & $\begin{array}{l}80.5 \\
19.5 \\
0.0\end{array}$ \\
\hline $\begin{array}{l}\text { Gender } \\
\text { Male } \\
\text { Female } \\
\end{array}$ & $\begin{array}{c}49 \\
228\end{array}$ & $\begin{array}{l}17.7 \\
82.3\end{array}$ \\
\hline $\begin{array}{l}\text { Educational qualification } \\
\text { Diploma Degree in Nursing } \\
\text { Nursing Institute } \\
\text { Bachelor Degree in Nursing } \\
\text { Others }\end{array}$ & $\begin{array}{c}24 \\
91 \\
152 \\
10\end{array}$ & $\begin{array}{c}8.7 \\
32.9 \\
54.9 \\
3.6\end{array}$ \\
\hline $\begin{array}{l}\text { Marital status } \\
\text { Married } \\
\text { Unmarried }\end{array}$ & $\begin{array}{c}215 \\
62 \\
\end{array}$ & $\begin{array}{l}77.6 \\
22.4 \\
\end{array}$ \\
\hline $\begin{array}{l}\text { Units } \\
\text { Pediatric care unit } \\
\text { Emergency care unit } \\
\text { Incubator unit } \\
\text { Dialysis unit } \\
\text { Intensive care unit } \\
\text { Intermediate care unit } \\
\text { Cardiac care unit } \\
\text { Chest care unit } \\
\text { Coronary care unit }\end{array}$ & $\begin{array}{l}30 \\
23 \\
34 \\
38 \\
60 \\
18 \\
25 \\
16 \\
33\end{array}$ & $\begin{array}{c}10.8 \\
8.3 \\
12.3 \\
13.7 \\
21.7 \\
6.5 \\
9.0 \\
5.8 \\
11.9\end{array}$ \\
\hline $\begin{array}{l}\text { Years of experience } \\
<10 \text { years } \\
10-15 \text { years } \\
>15 \text { years }\end{array}$ & $\begin{array}{c}245 \\
26 \\
6 \\
\end{array}$ & $\begin{array}{c}88.4 \\
9.4 \\
2.2 \\
\end{array}$ \\
\hline $\begin{array}{l}\text { Courses } \\
\text { Yes } \\
\text { No }\end{array}$ & $\begin{array}{l}159 \\
118\end{array}$ & $\begin{array}{l}57.4 \\
42.6\end{array}$ \\
\hline
\end{tabular}

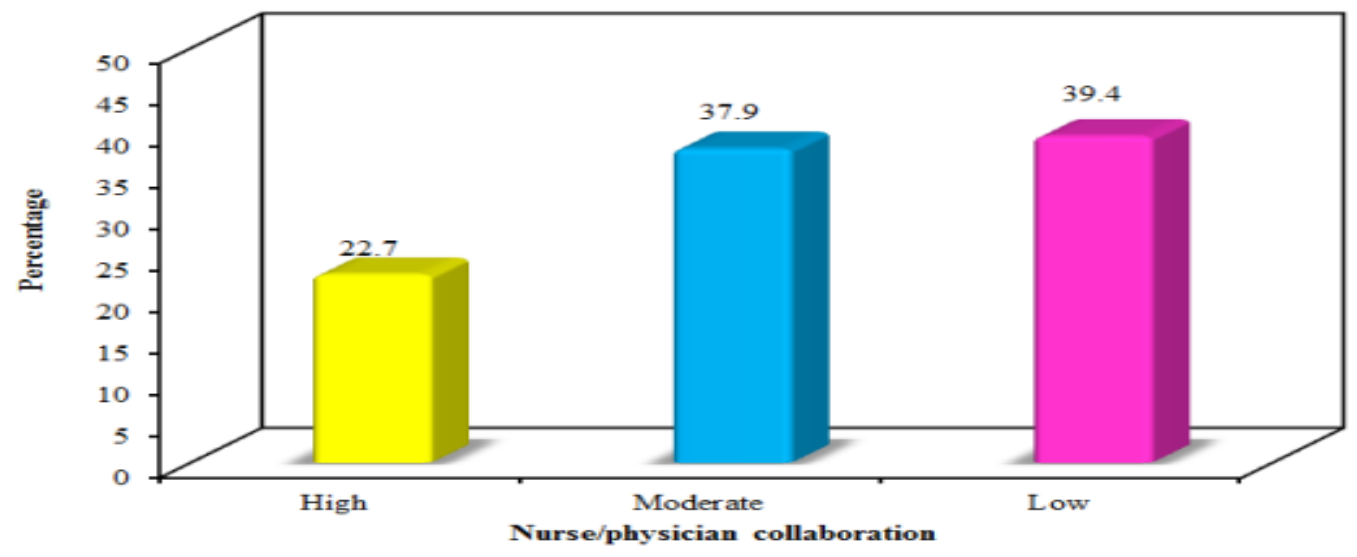

Figure (1):Total perception levels of nurses regarding nurse physician collaboration. 
Table (2): Total perception levels of nurses regarding nurse/physician collaboration dimensions $(\mathbf{n}=\mathbf{2 7 7})$.

\begin{tabular}{||l|c|c|c|c|c|c|}
\hline \multirow{2}{*}{ Nurse/physician collaboration dimensions } & \multicolumn{2}{|c|}{ Low } & \multicolumn{2}{c|}{ Moderate } & \multicolumn{2}{c|}{ High } \\
\cline { 2 - 7 } & No. & $\mathbf{\%}$ & No. & $\mathbf{\%}$ & No. & \% \\
\hline Joint participation in cure / care decision making & 134 & 48.4 & 69 & 24.9 & 74 & 26.7 \\
\hline Sharing of patients' information & 52 & 18.8 & 130 & 46.9 & 95 & 34.3 \\
\hline Degree of cooperation & 89 & 32.1 & 116 & 41.9 & 72 & 26.0 \\
\hline \multicolumn{1}{|c|}{ Total } & $\mathbf{1 0 9}$ & $\mathbf{3 9 . 4}$ & $\mathbf{1 0 5}$ & $\mathbf{3 7 . 9}$ & $\mathbf{6 3}$ & $\mathbf{2 2 . 7}$ \\
\hline
\end{tabular}

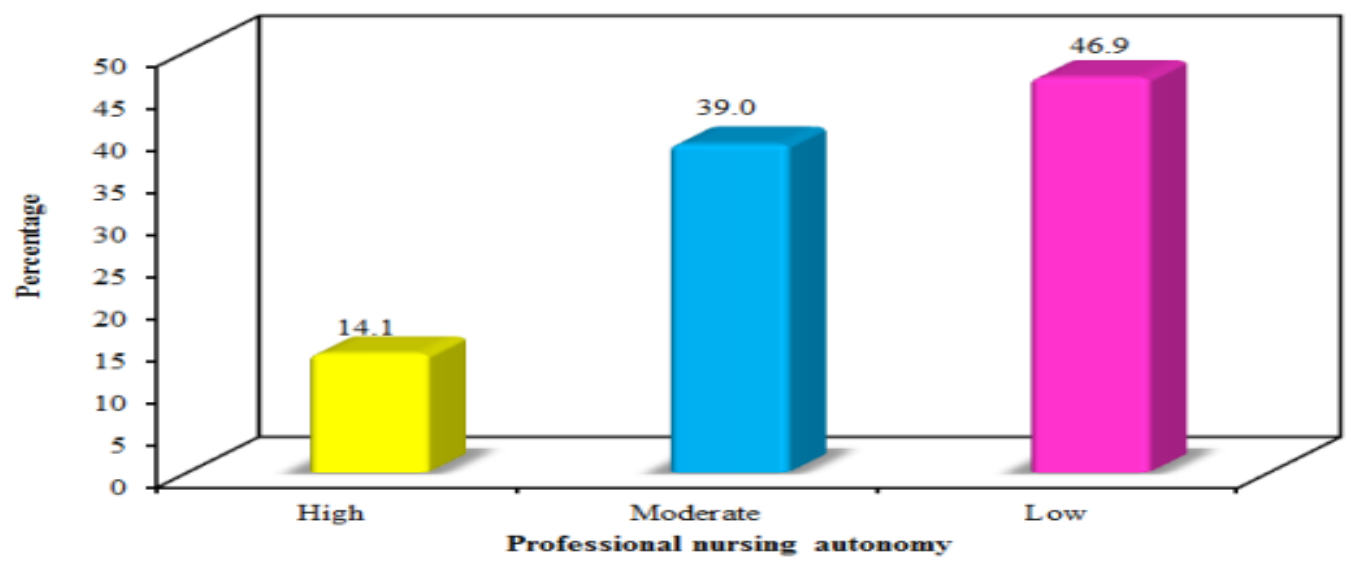

Figure (2): Total perception levels of nurses regarding professional nursing autonomy

Table (3): Correlation between nurses' perception regarding nurse/physician collaboration and professional nursing autonomy $(\mathbf{n}=\mathbf{2 7 7})$.

\begin{tabular}{|c|c|c|c|c|c|}
\hline \multirow[b]{2}{*}{$\begin{array}{c}\text { Professional nursing autonomy } \\
\text { dimensions }\end{array}$} & & \multicolumn{4}{|c|}{ Nurse/physician collaboration dimensions } \\
\hline & & $\begin{array}{c}\text { Joint } \\
\text { participatio } \\
\text { n in cure / } \\
\text { care } \\
\text { decision } \\
\text { making }\end{array}$ & $\begin{array}{l}\text { Sharing of } \\
\text { patients' } \\
\text { informatio } \\
n\end{array}$ & $\begin{array}{c}\text { Degree of } \\
\text { cooperatio } \\
\mathbf{n}\end{array}$ & Overall \\
\hline $\begin{array}{l}\text { Nursing practice environment for } \\
\text { nurses }\end{array}$ & $\begin{array}{l}\mathbf{r} \\
\mathbf{p}\end{array}$ & $\begin{array}{c}0.439 \\
<0.001^{* * *}\end{array}$ & $\begin{array}{c}0.313 \\
<0.001^{* * *}\end{array}$ & $\begin{array}{c}0.323 \\
<0.001^{* * *}\end{array}$ & $\begin{array}{c}0.464 \\
<0.001^{* * *}\end{array}$ \\
\hline Nursing care management & $\begin{array}{l}\mathbf{r} \\
\mathbf{p}\end{array}$ & $\begin{array}{c}0.632 \\
<0.001^{* *}\end{array}$ & $\begin{array}{c}0.433 \\
<0.001^{* * *}\end{array}$ & $\begin{array}{c}0.427 \\
<0.001^{* *}\end{array}$ & $\begin{aligned} & 0.652 \\
&<0.001^{* *}\end{aligned}$ \\
\hline $\begin{array}{l}\text { Educational background for } \\
\text { nurses }\end{array}$ & $\begin{array}{l}\mathbf{r} \\
\mathbf{p}\end{array}$ & $\begin{array}{c}0.460 \\
<0.001^{* *}\end{array}$ & $\begin{array}{c}0.246 \\
<0.001^{* * *}\end{array}$ & $\begin{array}{c}0.460 \\
<0.001^{* *}\end{array}$ & $\begin{array}{c}0.489 \\
<0.001^{* *}\end{array}$ \\
\hline $\begin{array}{l}\text { Structural construction of } \\
\text { autonomy }\end{array}$ & $\mathbf{r}$ & $\begin{array}{c}0.600 \\
<0.001^{* *}\end{array}$ & $\begin{array}{c}0.397 \\
<0.001^{* *}\end{array}$ & $\begin{array}{c}0.465 \\
<0.001^{* * *}\end{array}$ & $\begin{array}{r}0.630 \\
<0.001^{* *}\end{array}$ \\
\hline $\begin{array}{l}\text { Behavioral trends of nurse's } \\
\text { autonomy }\end{array}$ & $\mathbf{r}$ & $\begin{array}{l}0.092 \\
0.126\end{array}$ & $\begin{array}{l}0.013 \\
0.831\end{array}$ & $\begin{array}{c}0.181 \\
0.002^{*}\end{array}$ & $\begin{array}{l}0.109 \\
0.071\end{array}$ \\
\hline Overall & $\begin{array}{l}\mathbf{r} \\
\mathbf{p}\end{array}$ & $\begin{array}{c}0.554 \\
<0.001^{* *}\end{array}$ & $\begin{array}{c}0.354 \\
<0.001^{* *}\end{array}$ & $\begin{array}{c}0.458 \\
<0.001^{* *}\end{array}$ & $\begin{array}{c}0.585 \\
<0.001^{* *}\end{array}$ \\
\hline
\end{tabular}

\section{r: Pearson coefficient}

*: Statistically significant at $\mathrm{p} \leq 0.05$

$* *$ : highly statistical significant $\mathrm{P} \leq 0.001$ 


\section{Discussion}

The present study showed that $(80.5 \%)$ of nurses had age less than 30years old and were females respectively. And (54.9\%) of them had Bachelor degree in nursing. In addition, (77.6\%) of nurses were married. Regarding unit, $(21.7 \%)$ of nurses was working at Intensive care unit. Concerning years of experience $(88.4 \%)$ of them had less than10 years .As well as, (57. 4 $\%$ ) of the nurses had taken courses.

The present study showed that (39.4\%) of nurses had low perception level regarding nurse physician collaboration.while, $(22.7 \%)$ of them had high perception level. This may be because the nurses are considered as a subordinate of physicians and taking their orders from physicians.

This finding was consistent with Amsalu et al (2014) who conducted a study about "Attitudes of nurses and physicians towards nurse-physician collaboration in northwest Ethiopia: a hospital based cross-sectional study" and showed that nurses were not satisfied with their collaboration with physicians

This finding was accordance with Suryanto et al (2016) who conducted a study about "Collaboration between nurses and physicians in an Indonesian emergency department" and showed that nurses had significantly higher scores and more positive attitudes towards collaboration

The present study showed that $(48.4 \%)$ of nurses had low perception level regarding Joint participation in cure / care decision making dimension and(46.9\%-41.9\%) of nurses had moderate perception level regarding sharing of patients' information and degree of cooperation dimensions. This may be because nurses don't have opportunity to participate in decisions regarding patient care.

This finding was consistent with Wang et al (2018) who conducted a study about "The influence of effective communication, perceived respect and willingness to collaborate on nurses' perceptions of nursephysician collaboration in China".and showed that nurses had low perception level regardingJoint participation in cure / care decision making.

The present study showed that $(46,9 \%)$ of nurses had low perception level about professional nursing autonomy, while, $(14,1 \%)$ of them had high perception level. This may be due to physicians' traditional mode of supervision and control, autocratic/non-supportive management, work overload and hospital rules. In addition, nurses are working at a governmental hospital which has a lack of organizational support and the managers don't let them participate in decision making process. This result was not surprising considering that the majority of the respondents in the current study was new in the profession, had less clinical experiences, and was still adjusting to their role as nurses.

This finding was consistent with Sarkoohijabalbarezi et al (2017) who conducted a study was about " The relationship between professional autonomy and moral distress among nurses working in children's units and pediatric intensive care wards" and found low levels of professional nursing autonomy among nurse.Also, It was consistent with Mansour (2017) who conducted a study about "Hospital forces as perceived by nurses at Ain Shams Specialized Hospital" and reported that, autonomy perception had low score among nurses. 
This finding was incongruent with Eladly, (2014) who conducted a study about "The influence of organizational climate on nurses' autonomy" and showed that nurses had moderate levels of autonomy. Also, Laschinger et al., (2011) who conducted a study about "Impact of structural and psychological empowerment on job autonomy in nursing work settings" and found that more half of nurses were perceived a high autonomy level.

This part answered third research question" Regarding Correlation between nurses' perception regarding nurse/physician collaboration and professional nursing autonomy.

This finding was consistent with Papathanassoglou et al (2012) who conducted a study about" professional autonomy, collaboration with physicians, and moral distress among European intensive care nurses" and found a relation between Professional autonomy and nurse/physician collaboration.

This finding was incongruent with Aghamohammadi et al (2019) who conducted a study about "Nurse-Physician Collaboration and the Professional Autonomy of Intensive Care Units Nurses" and found that there was no significant relationship between the nurses' attitudes toward the nurse-physician collaboration and the professional autonomy of nurses. The present study showed that there was a highly statistical significant positive correlation between overall nurses' perception regarding nurse/physician collaboration and overall professional nursing autonomy.

\section{Conclusion}

The present study concluded that nearly two fifths of nurses had low perception level regarding nurse / physician collaboration .while; more than one fifth of them had high perception level. In addition, more than two fifth of nurses had low perception level about professional nursing autonomy, while, less than one fifth of them had moderate perception level. There was a highly statistical significant positive correlation between overall nurses' perception regarding nurse/physician collaboration and overall professional nursing autonomy.

\section{Recommendations}

In the light of the findings obtained from the present study, these points are recommended:

Administrative level:

- Empowering nurses with adequate authority to implement the hospital policies

- Providing well-planned orientation program for physicians and nurses, which covers the roles of the health team members, policies and procedure. Administrators have to be fair and apply disciplinary action equally to nurses and physicians

- Providing an inter-professional collaborative environment as a vital part of healthcare organization development to promote nurses' performance as well as improve patient safety climate.

- Provide a useful training strategy to enhance nurses and physicians work together and recognize the autonomy and competence of each profession before entering hospitals

- Fostering nurses' autonomy by enabling them to exercise clinical decisionmaking, first in safe environments, such as nursing rounds, and then by implementing multi-professional teams. Actively supporting nursing decisions 
and nursing accountability

- Providing opportunity for nurses to participate in the treatment and discharge plan of patient with physicians.

\section{Education level:}

- Developing educational program about nurse/ physician collaboration for new nurses.

- Increasing the practical training of nurses during their study to enhance their professional autonomy.

- Improve the relationship, collaboration and communication between physicians and nurses through sharing in conferences, seminars, also shared continuing educational, in service programs and workshop especially these with a focus on collaboration and communication

\section{Further research level:}

- There is a need for further studies that explain the important factors that hindering inters professional collaboration and its negative outcomes.

- Further research is needed to examine the barriers to decision making autonomy among nurses

\section{References}

Aghamohammadi, D., Dadkhah, B. and Aghamohammad, M. (2019). Nurse/Physician Collaboration and the Professional Autonomy of Intensive Care Units Nurses. Indian Journal of Critical Care Medicine, 23(4): 178-181.

Amsalu, E., Boru, B., Getahun, F. and Tulu, B. (2014). Attitudes of Nurses and Physicians towards Nurse / Physician Collaboration in Northwest Ethiopia: A Hospital Based Cross-Sectional Study. BMC Nursing, 13(1):37.
Direko, K. and Davhana-Maselesele, M. (2017). "A Model of Collaboration between Nursing Education Institutions in the North West Province of South Africa", Curationis 40(1): a1670.

El-Adly, A. (2014). The Influence of Organizational Climate on Nurses' Autonomy, UN published Master Thesis, Faculty of Nursing, Ain Shams University.

El-Hanafy, E. (2018). Nurse /Physician Work-Related relationship as Perceived by Both of them. Egyptian Nursing Journal,15 (2):188-195.

El-ksas, E. (2017). Professional Nursing Autonomy and Organizational Support: Staff Nurses' Perspective, Un Published Master Thesis, Faculty of Nursing, Alexandria University.

El-Sayed, K. and Sleem, W. (2011). Nurse/Physician collaboration: A Comparative Study of the Attitudes of Nurses and Physicians at Mansoura University. Life Science Journal, 8 (2): 140-146.

Elsous, A., Radwan, M. and Mohsen, S. (2017). Nurses and Physicians Attitudes toward Nurse-Physician Collaboration: A Survey from Gaza Strip Palestine. Nursing Research and Practice, (6):1-7.

Friganović, A., Selič, P., Ilić, B. and Sedić, B. (2019). Stress and Burnout Syndrome and their Associations with Coping and Job Satisfaction in Critical Care Nurses: A Literature Review. PsychiatrDanub,31(1):21-31. 
Fritter, E. and Shimp, K. (2016):What does Certification in Professional Nursing Practice Mean? Med Surgical Nursing, 25(2): 8-10.

Galletta, M., Portoghese, I., Carta, M., D'Aloja, E. and Campagna, M. (2016). The Effect of Nurse-Physician Collaboration on Job Satisfaction, Team Commitment, and Turnover Intention in Nurses. Res Nursing Health,39(5):375385 .

Georgiou, E., Papathanassoglou, E. and Pavlakis, A. (2017). Nurse-Physician Collaboration and Associations with Perceived Autonomy in Cypriot Critical Care Nurses. Nursing Critical Care, 22(1):29-39.

Gitlin, L., Lyons, K. and Kolodner, E. (1994). A Model to Build Collaborative Research Educational Teams of Health Professionals in Gerontology. Educational Gerontology, 20: 15-34.

Kuwano, N., Fukuda, H. and Murashima, S. (2016). Factors Affecting Professional Autonomy of Japanese Nurses Caring for Culturally and Linguistically Diverse Patients in A Hospital Setting in Japan. Journal of Trans cultural Nursing, 27(6): 567-573.

Mansour, M. (2017). Hospital Forces as Perceived by Nurses at Ain Shams Specialized Hospital. Un published Master Thesis, Faculty of Nursing, Ain Shams University.

Motamed-Jahromi, M., Jalali, T., Eshghi, F., Zaher, H. and Dehghani, L. (2015). Evaluation of Professional Autonomy and the Association with Individual Factors among Nurses in the Southeast of Iran. Journal of Nursing and Midwifery Sciences, 2: 37- 42 .

Rapetti, R., Fiorini, B., Puntoni, M., DeCensi, A. and Lo Pinto, G. (2014). The Nurse/Physician Collaboration: A Survey among Internal Medical Units in Liguria Region. Italian Journal of Medicine, 8(4): 238-245.

Shohani, M., Rasouli, M. and Sahebi, A. (2018). The Level of Professional Autonomy in Iranian Nurses. Journal of Clinical and Diagnostic Research, 12 (5): 1-4.

Starmer, A., Spector, N., Srivastava, R., West, D., Rosenbluth, G., Allen, A., Noble, E., Tse, L., Dalal, A., Keohane, C., Lipstiz, S. and Rothschild, J., et al.(2014). Changes in Medical Errors after Implementation of A Handoff Program. New England Journal of Medicine, 371: 1803-1812. 
تعاون الممرضة والطبيب وعلاقته باستقلالية مهنة التمريض من وجهة نظر الممرضين

مبروكة حمدي تحمد الثامي- صفاء حمح الدمرداش- أيه غنيمى حسنين

يعتبر التعاون بين الممرض و الطبيب عملية معقدة وهذه العملية تعتمد علي الاستقلال المهني. لذا هدفت هذه الدر اسة إلى إدر الك العلاقة بين تعاون الممرضة والطبيب واستقلالية مهنة التمريض من وجهة نظر الممرضين وقد أجريت هذه الدراسة في وحدات الرعاية الحرجة بمستثفى بنها الجامعي و اشتملت هذه الدر اسة على جميع الممرضين في هذه الوحدات وكان عددهم rVV. حيث كثفت النتائج بان هناك علاقة ذات دلالة إحصائية عالية بين إدراك الممرضين للعلاقة بين تعاون الممرضة و الطبيب واستقلالية مهنية التمريض.كما أوصت الدراسة بان هنالك حاجة إلى مزيد من الدراسات التي تشرح العو امل الهامة التي تعيق التعاون المهني بين الممرضين والأطباء ونتائجه السلبية. 